\title{
Reliability Analysis for Rainwater Harvesting System in Peri-Urban Regions of Greater Sydney, Australia
}

\author{
E. Hajani ${ }^{1}$, A. S. Rahman ${ }^{2}$, M. Al-Amin ${ }^{3}$ and $\underline{\text { A. Rahman }}{ }^{2}$ \\ ${ }^{1}$ School of Engineering, University of Duhok, Iraq \\ ${ }^{2}$ School of Computing Engineering and Mathematics, University of Western Sydney, Australia \\ ${ }^{3}$ School of Public Health and Preventive Medicine, Monash University, Australia \\ Email: a.rahman@uws.edu.au
}

\begin{abstract}
Rainwater harvesting has become quite popular in Australia in recent years. In metropolitan areas, rainwater tanks are used to save mains water, but in peri-urban and rural areas, rainwater tanks are used as the principal water source to many households. In this case, the reliability of rainwater tank to meet given water demand is important. This study presents development of a rainwater tank model that can determine the tank size which can meet the most of the water demand in peri-urban areas. The model is a continuous simulation type, with daily time step.
\end{abstract}

The model is applied to 10 different locations in Greater Sydney and assesses the feasibility of 8 different rainwater tank sizes, $1 \mathrm{~kL}$ to $20 \mathrm{~kL}$. Nine of these ten locations are situated in the peri-urban areas of Greater Sydney, which are Campbelltown, Hornsby, Penrith, Richmond, Castlereagh, Wallacia, West Pennant Hills, Moss Vale, and Cataract Dam. The other location (Parramatta) is situated in the approximate centre of the Greater Sydney, which is used for bench marking the water use in peri-urban and metropolitan Sydney regions. The daily rainfall data at each of the ten selected locations was obtained from the Australian Bureau of Metrology. The rainfall data lengths were in the range of 31 to 150 years, with an average of 73 years.

It has been found that for toilet and laundry use, a $7.5 \mathrm{~kL}$ tank can meet almost $100 \%$ of the demand, but to meet the irrigation demand, a much larger tank is needed. It has been shown that irrigation demand cannot be met $100 \%$ even with a tank size of $20 \mathrm{~kL}$. The method presented in this paper can also be applied to other Australian states and countries to estimate water savings and reliabilities of rainwater harvesting system using daily rainfall data.

Keywords: Rainwater tanks, rainwater harvesting system, peri-urban area, water sensitive urban design, reliability, water conservation 
Hajani, Rahman, Al-Amin and Rahman, Reliability Analysis for Rainwater Harvesting System in Peri-Urban Regions of Greater Sydney, Australia

\section{INTRODUCTION}

Rainwater tank has become popular in recent years in Australia (Rahman et al., 2012). This is due to a greater environmental awareness among the general public, a long-lasting drought in the last decade and subsidy provided by various government authorities in Australia to install a rainwater harvesting system (RWHS) (Coombes et al., 2003). Among all the alternative water sources, the most popular one is the RWHS as it is a simple low-cost technique requiring minimum expertise to operate and offers multiple benefits. Most of the local councils in Australia encourage installation of rainwater tanks by providing financial rebate for RWHS (Eroksuz and Rahman, 2010).

Some major advantages of the RWHS in urban areas include saving mains water and achieving a greater flexibility in water use during water restriction period as rainwater can be used for non-potable purposes such as gardening, washing of cars and hard surfaces during the period of water restrictions imposed by urban authorities during low water level in reservoirs. However, in rural and peri-urban regions of Australia where mains water is not available, RWHS are used to source water for meeting principal water demand such as drinking, washing and gardening. It should be recognized that, the design of a RWHS is concerned with determining the storage capacity required to maintain enough water in the tank to ensure water supply for the desired purposes without much reliance on other water sources. In this regard, reliability can be defined as the proportion of days when a RWHS is likely to meet the required water demand. An unnecessarily large tank is a misuse of resources and space; on the other hand, a RWHS, which is too small, may not serve its intended purpose and there is likely to be a shortage of water from the tank on a regular basis, and users will have to depend on other water sources. Hence, a RWHS should be designed according to the need of the household and a common size is not the best solution in most locations.

In recent years, in many places of the world, numerous studies have demonstrated the benefit of having a RWHS in a house. In Australia, Coombes et al. (2003) examined the performance of a RWHS in an old house in Maryville inner city suburb of Newcastle. They considered three common water uses i.e. toilet, hot water and outdoor. Ghisi et al. (2009) evaluated the financial viability of installing a RWHS in five towns in Santa Catarina State in southern Brazil where they considered car washing at petrol stations in the City of Brasilia. The results showed that an increase in the tank size enhanced the reliability of the rainwater tank notably in meeting the desired demand.

Domènech and Sauri (2010) examined the efficiency of RWHS for the two main types of buildings prevalent in the Metropolitan area of Barcelona (Spain) by analysing users' practices and perceptions, drinking water savings and economic costs. They carried out the financial viability of the RWHS in single and multi-family buildings and found that in single-family households an expected payback period would be between 33 to 43 years depending on the tank size and for a multi-family building a payback period was 61 years for a $20 \mathrm{~m}^{3}$ tank. In Australian studies by Van der Sterren et al. (2009, 2012 and 2013) it was found that although RWHS can be very useful to provide required water in peri-urban regions of Sydney, water quality may not always meet the drinking water standard in relation to heavy metals and pathogens. They also found that RWHS can enhance the stormwater runoff quality, which in turn would enhance the urban waterways health. Kus et al. (2011) compared the water quality with the Australian Guidelines for Water Recycling (2009). They used eleven rainwater tanks located in the Sydney metropolitan area and five rainwater tanks located in peri-urban regions of Sydney. They demonstrated that simple yet effective treatments could bring the water quality to desired standards for non-potable uses.

Imteaz et al. (2011a) proposed a daily water balance model for optimisation of RWHS within the campus of Swinburne University of Technology in Melbourne, Australia. They demonstrated the usefulness of large rainwater tanks when these are connected with large roof areas. Furthermore, they found that total construction costs of RWHS can be recovered within 15 to 21 years depending on the tank size, climatic conditions and future water price increase rate. Rahman et al. (2012) examined the water savings potential, reliability of water supply, financial benefits, and the adequacy of the current government rebate for a RWHS in detached house at ten different locations in Greater Sydney, Australia. They suggested that government authorities in Sydney should maintain or possibly increase the rebate for the RWHS to enhance its acceptance.

This study investigates the potential of a RWHS in peri-urban areas of Greater Sydney where semi-rural and rural properties depend on RWHS to meet most of their household water needs including drinking, washing and irrigation. Here, reliability of a RWHS is quite important as there is no mains water to supplement the RWHS. In this case, if a RWHS cannot meet the demand, water is to be bulk supplied into the tank, or an 
Hajani, Rahman, Al-Amin and Rahman, Reliability Analysis for Rainwater Harvesting System in Peri-Urban Regions of Greater Sydney, Australia

alternative groundwater well/bore needs to be built. Furthermore, self-imposed restriction may need to be exercised so that the supply does not run out.

\section{STUDY AREA AND DATA}

In this study, ten different locations in Greater Sydney are considered as shown in Figure 1. Nine of these ten locations are situated in the peri-urban regions of Greater Sydney, which are Campbelltown, Hornsby, Penrith, Richmond, Castlereagh, Wallacia, West Pennant Hills, Moss Vale, and Cataract Dam. The other location (Parramatta) is situated in the approximate centre of the Greater Sydney, which is used for bench marking the water use in peri-urban and metropolitan Sydney regions. For each of these ten locations, a daily rainfall station was selected and the data was obtained from Australian Bureau of Metrology (the list of stations is provided in Table 1).The data lengths were in the range of 31 years to 150 years, with an average of 73 years. The average monthly rainfall distribution in the Greater Sydney region is shown in Figure 2, which shows that July to Sep are the lowest rainfall months, which are also the winter season requiring very little irrigation due to minor gardening activity in this region during winter months.

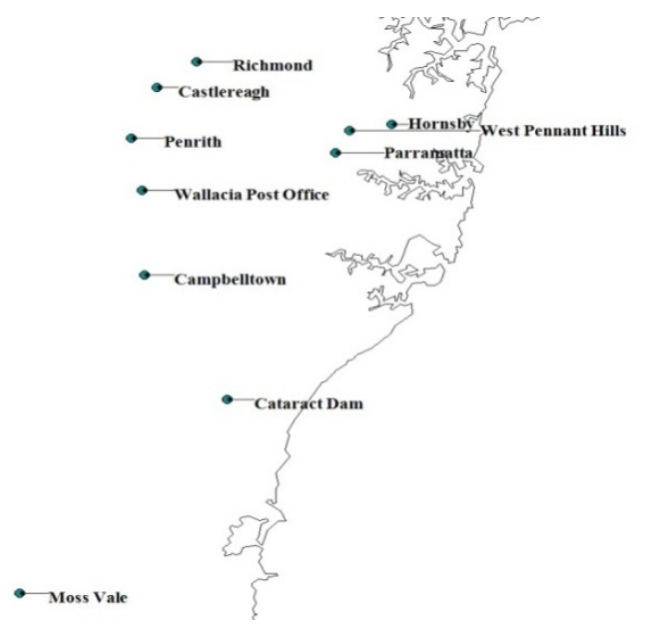

Figure 1. Ten different locations in Greater Sydney selected in this study

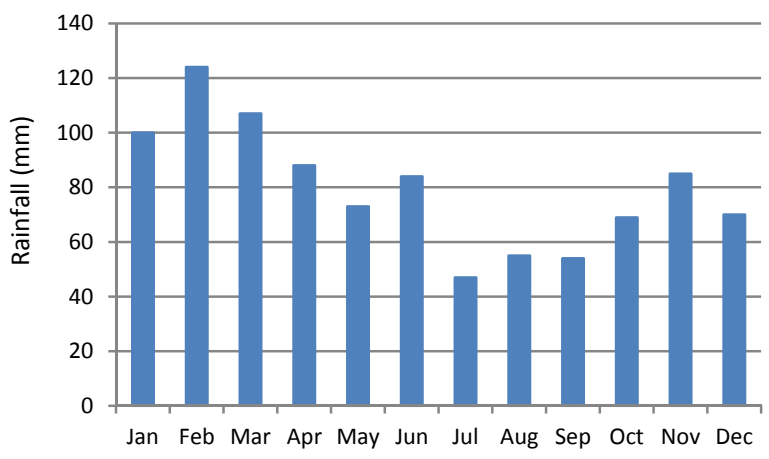

Figure 2. Average monthly rainfall in Sydney region

In this study, three different combinations of water use were considered: (i) toilet and laundry (ii) irrigation and (iii) a combination of toilet, laundry and irrigation (combined use). The feasibility of 8 different rainwater tank sizes, from $1 \mathrm{~kL}$ to $20 \mathrm{~kL}$ was examined. A hypothesized new development was considered at each of the study locations with a single household having 4 occupants. A total site area of $450 \mathrm{~m}^{2}$ was considered with a roof, lawn and impervious areas of $200 \mathrm{~m}^{2}, 150 \mathrm{~m}^{2}$ and $100 \mathrm{~m}^{2}$, respectively. The rainwater tank was considered to be located above ground. The water demand data for toilet, laundry and irrigation use for residential properties were obtained from Sydney Water. The toilet considered in the study was a 6-litre AAA rated dual flush toilet, and a frequency of toilet use of three times per person per day was assumed, which was equivalent to $0.018 \mathrm{~kL}$ of water use per person per day. The washing machine considered in this study was rated AAAA. It was assumed that the washing machine had a volume of 50 liters and it would be 
Hajani, Rahman, Al-Amin and Rahman, Reliability Analysis for Rainwater Harvesting System in Peri-Urban Regions of Greater Sydney, Australia

used 3 times per week, which was equivalent to $0.0215 \mathrm{~kL} /$ day of water use. The irrigation demand per square meter of lawn area was assumed to be $10 \mathrm{~mm}$ per day as per Sydney Water recommended value in this region.

Table 1 Study locations and details of selected daily rainfall data

\begin{tabular}{|c|c|c|c|}
\hline Location & Rainfall station & Period of rainfall record & Average annual rainfall (mm) \\
\hline Campbelltown & 068007 & $1900-2009$ & 743 \\
\hline Hornsby & 066158 & $1936-2009$ & 963 \\
\hline Parramatta & 066124 & $1970-2009$ & 971 \\
\hline Penrith & 063185 & $1902-2003$ & 800 \\
\hline Richmond & 067021 & $1939-2011$ & 685 \\
\hline Castlereagh & 067002 & $1943-2011$ & 847 \\
\hline Wallacia Post Office & 067029 & $1943-2006$ & 1,028 \\
\hline West Pennant Hills & 067098 & $1971-2009$ & 1,089 \\
\hline Moss Vale & 068195 & $1935-2011$ & 1,080 \\
\hline
\end{tabular}

\section{WATER BALANCE MODEL}

In this study, to simulate the performance of a RWHS, a water balance simulation model (WBSM) on daily time scale was built in Excel. The developed model accounted for various factors for a RWHS such as tank size, daily rainfall, losses, daily water demand, mains top up and tank spillage. The adopted approach was very similar to Su et al. (2009) and Rahman et al. (2012).

The rainfall was regarded as inflow and the release and possible spill as outflow. The release was estimated based on the following equations:

$$
\begin{array}{ll}
\mathrm{R}_{\mathrm{t}}=\mathrm{D}_{\mathrm{t}} & \text { if } \mathrm{I}_{\mathrm{t}}+\mathrm{S}_{\mathrm{t}-1} \geq \mathrm{D}_{\mathrm{t}} \\
\mathrm{R}_{\mathrm{t}}=\mathrm{I}_{\mathrm{t}}+\mathrm{S}_{\mathrm{t}-1} & \text { if } \mathrm{I}_{\mathrm{t}}+\mathrm{S}_{\mathrm{t}-1}<\mathrm{D}_{\mathrm{t}}
\end{array}
$$

Where $D_{t}$ is the daily demand $\left(\mathrm{m}^{3}\right)$ on day $t, S_{t-1}$ is the tank storage at the end of the previous day $\left(\mathrm{m}^{3}\right), \mathrm{R}_{t}$ is release from rainwater tank $\left(\mathrm{m}^{3}\right)$ and $I_{t}$ is inflow $\left(\mathrm{m}^{3}\right)$. Spill $\mathrm{SP}_{t}\left(\mathrm{~m}^{3}\right)$ is calculated from the following equations:

$$
\begin{array}{ll}
S_{t}=I_{t}+S_{t-1}-D_{t}-S_{M A X} & \text { if } I_{t}+S_{-1}-D_{t}>S_{M A X} \\
S P_{t}=0 & \text { if } I_{t}+S_{-1}-D_{t} \leq S_{\text {MAX }}
\end{array}
$$

Where $S_{\text {MAX }}$ is the design storage capacity $\left(\mathrm{m}^{3}\right)$. The tank storage $S_{t}$ at the end of day $t$ was calculated using the following equations:

$$
\begin{array}{lr}
\mathrm{S}_{\mathrm{t}}=\mathrm{S}_{\text {MAX }} & \text { if } \mathrm{SP}_{\mathrm{t}}>0 \\
\mathrm{~S}_{\mathrm{t}}=\mathrm{S}_{\mathrm{t}-1}+\mathrm{I}_{\mathrm{t}}-\mathrm{R}_{\mathrm{t}} & \text { if } \mathrm{SP}_{\mathrm{t}} \leq 0
\end{array}
$$

The reliability of RWHS was calculated as the ratio of the number of days when the intended demand was met fully by the available rainwater and the total number of simulated days.

\section{RESULTS}

The reliability of rainwater tanks of different sizes and water use across all the ten locations are shown in Figures 3 and 4. Figure 3 shows that on average $1 \mathrm{~kL}$ rainwater tank can meet the demand for toilet and laundry use for $87 \%$ of the days in a year, which increases to $97 \%$ for a $5 \mathrm{~kL}$ tank size and $100 \%$ for a $20 \mathrm{~kL}$ tank size. Among the ten locations considered here, Hornsby has the highest reliability $(99.26 \%$ for a $5 \mathrm{~kL}$ tank) and Castlereagh has the lowest one (79\% for a $5 \mathrm{~kL}$ tank). This reliability is well related with the average annual rainfall values at these two locations $(1,325 \mathrm{~mm}$ and $685 \mathrm{~mm}$ for Hornsby and Castlereagh, respectively). 
Hajani, Rahman, Al-Amin and Rahman, Reliability Analysis for Rainwater Harvesting System in Peri-Urban Regions of Greater Sydney, Australia

Figure 3 also shows that the differences in reliability across different locations reduces as the tank size increases and a rainwater tank of $7.5 \mathrm{~kL}$ size can meet the demand for toilet and laundry use for about $100 \%$ at the nine locations; on the other hand, a rainwater tank of $7.5 \mathrm{~kL}$ size can meet the demand for toilet and laundry use for about $85 \%$ at Castlereagh. This suggests that in peri-urban areas of Sydney, a $7.5 \mathrm{~kL}$ rainwater tank should be adopted to meet toilet and laundry demands to ensure reliable supply and to maximize water conservation.

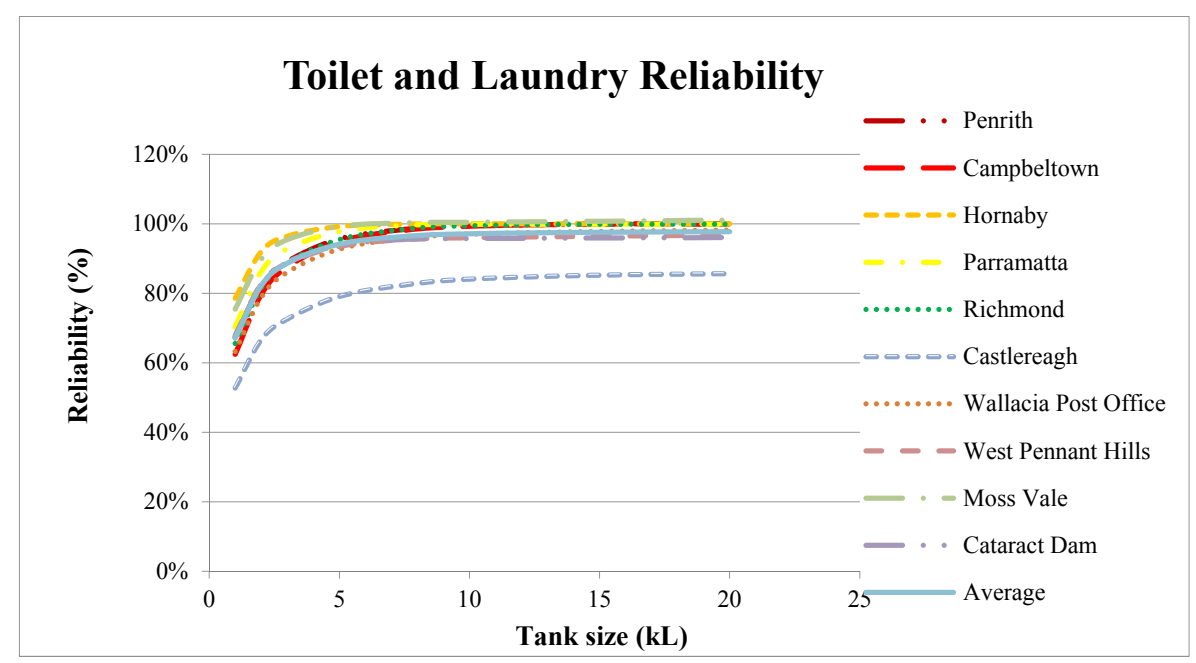

Figure 3. Reliability of rainwater tanks at ten selected locations for toilet and laundry use

It is found that the reliability for irrigation use at all the ten locations is smaller than for toilet and laundry use. For a $20 \mathrm{~kL}$ tank, the reliability values for Hornsby and Castlereagh are $82 \%$ and $41 \%$, respectively. This result shows that reliability value varies significantly at these two locations, which is well related with the average annual rainfalls (mean annual rainfall of $1,325 \mathrm{~mm}$ and $685 \mathrm{~mm}$ for Hornsby and Castlereagh, respectively). The average reliability for the ten locations is very close to the reliability of West Pennant Hills. These results highlight that even with a $20 \mathrm{~kL}$ rainwater tank, the reliability of $100 \%$ cannot be achieved for irrigation use at any of the ten study locations. This is due to the fact of high irrigation demand in the Greater Sydney region, which is characterized by periods of drought spells lasting over weeks and even months in almost all the years on record.

Figure 4 presents reliability values for the toilet, laundry and irrigation use (combined use). It is found that the reliability increases with the increasing rainwater tank size as expected. The highest and lowest reliability values for a $5 \mathrm{~kL}$ tank are found to be for Hornsby (69\%) and Castlereagh (32\%), respectively, which is similar to the toilet and laundry use (see Figure 3). The average reliability over the ten locations is very close to the reliability for West Pennant Hills as can be seen in Figure 4. The reliability for combined use does not reach to $100 \%$ for any of the ten locations even for a $20 \mathrm{~kL}$ tank size. Furthermore, there is a notable difference in reliability across different locations in Sydney, which suggests that a common tank size is not appropriate for Greater Sydney as practiced currently.

Figure 5 shows the water savings for toilet and laundry use from a $7.5 \mathrm{~kL}$ rain water tank; after about $10 \mathrm{~kL}$ size, the water savings becomes nearly constant for all the ten locations. This is due to the fact that water utilization from tank depends on number of users in the house, and for a larger tank there would be much more unutilised water overflowing from the tank. For a $5 \mathrm{~kL}$ tank, average annual water savings range from $27 \mathrm{~kL}$ (Castlereagh) to $34 \mathrm{~kL}$ (Hornsby) with a mean value of $32 \mathrm{~kL}$, which suggests a smaller variation across the ten locations in water savings for toilet and laundry use.

Figure 6 shows that the differences in water savings for combined use for the ten different locations reduce as the size of rain water tanks reduces. The water saving increases with the increasing rain water tank size as expected. For a $5 \mathrm{~kL}$ tank, Penrith has the highest average annual water savings $(62 \mathrm{~kL})$, and Castlereagh has the lowest annual water savings $(50 \mathrm{~kL})$ and Wallacia corresponds very well to the average annual water savings over the ten locations $(56 \mathrm{~kL})$.

It should be noted here that the reliability reported in this study is based on the long-term daily rainfall data and represents the average reliability at a given location; the reliability will differ from year to year depending on the rainfall pattern of the location, e.g. for a wet year, reliability will be higher than a dry year, 
Hajani, Rahman, Al-Amin and Rahman, Reliability Analysis for Rainwater Harvesting System in Peri-Urban Regions of Greater Sydney, Australia

as found by Imteaz et al. ( 2011a, b; 2012; 2013).

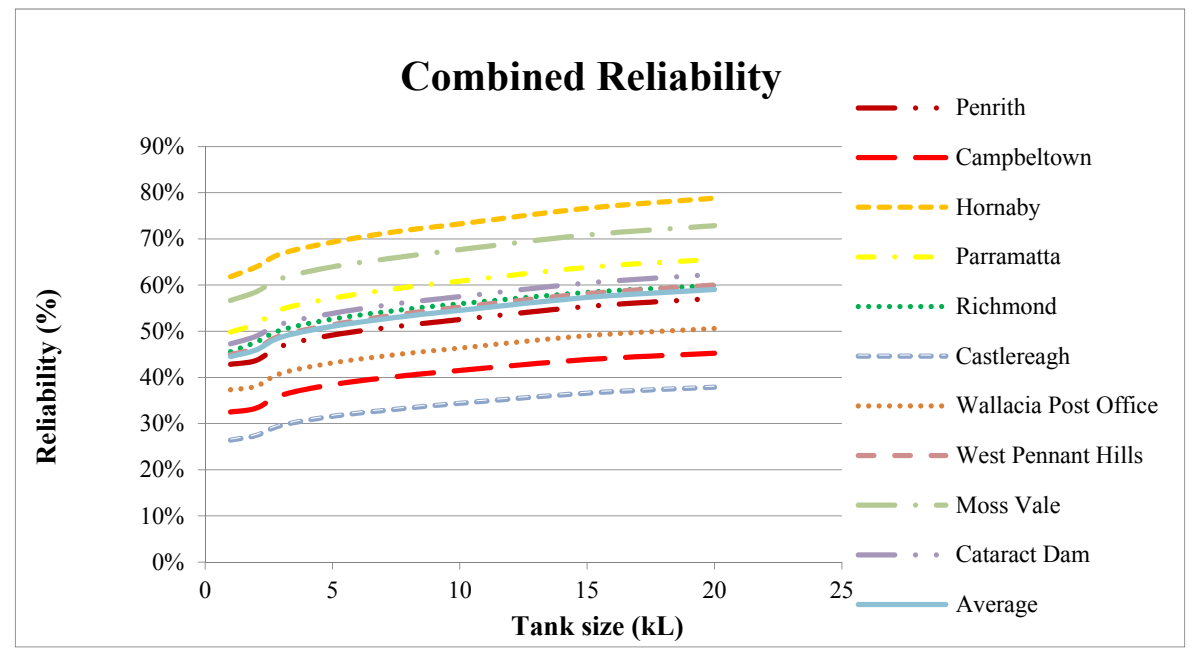

Figure 4. Reliability of rainwater tanks at the ten selected locations for combined use

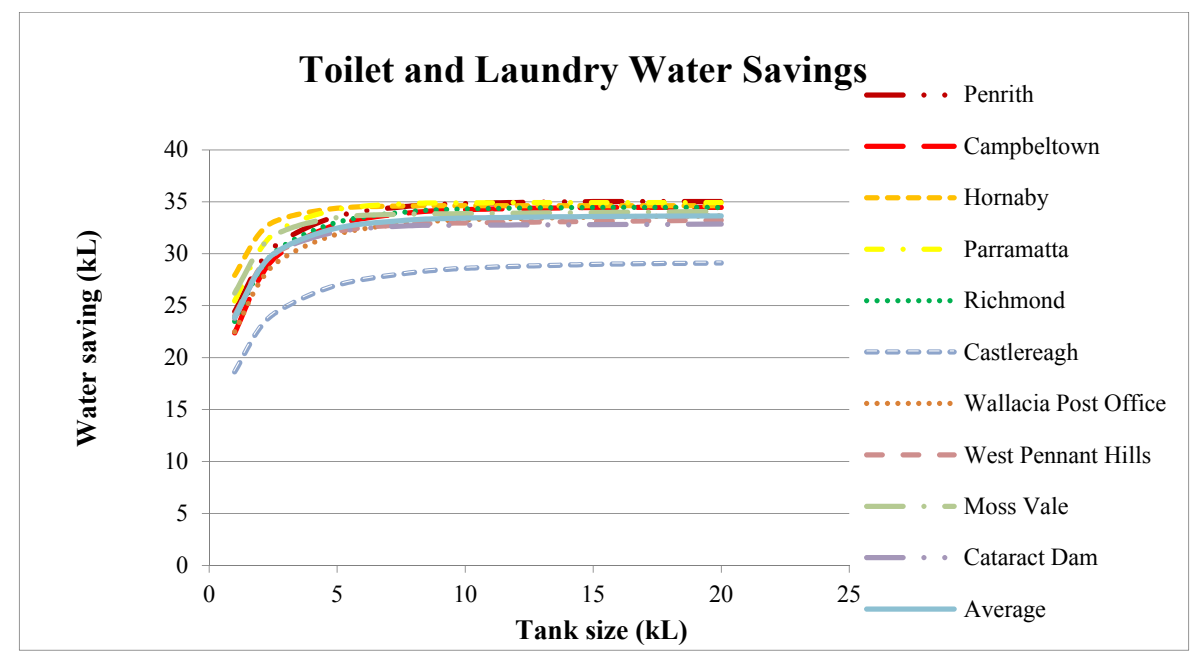

Figure 5. Water savings for toilet and laundry use

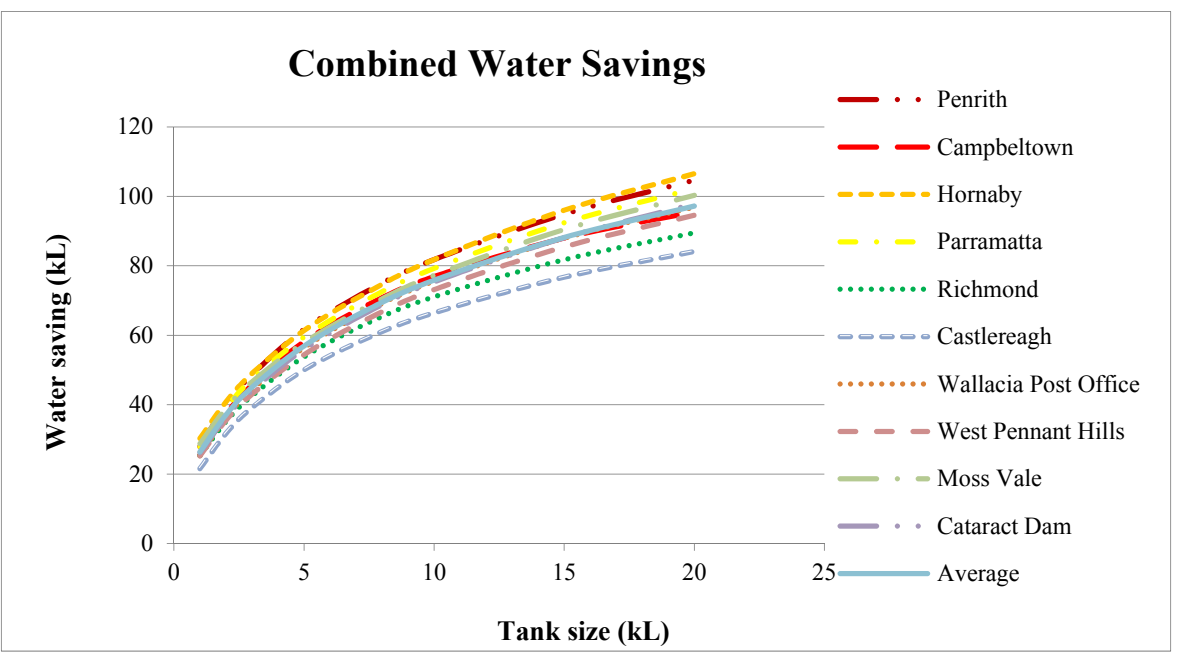

Figure 6. Water savings for combined use 
Hajani, Rahman, Al-Amin and Rahman, Reliability Analysis for Rainwater Harvesting System in Peri-Urban Regions of Greater Sydney, Australia

\section{CONCLUSIONS}

This paper investigates the performance of a rainwater harvesting system (RWHS) in peri-urban regions of Greater Sydney, Australia. Ten locations are selected from the peri-urban regions of Greater Sydney. It has been found that reliability of water supply increases as tank size increases for all the three water use considered here. For toilet and laundry use, a $7.5 \mathrm{~kL}$ tank can meet almost $100 \%$ of the demand, and hence this is the recommended tank size in peri-urban regions of Sydney. However, irrigation demand cannot be met $100 \%$ of the days in a year even with a tank size of $20 \mathrm{~kL}$.

\section{ACKNOWLEDGMENTS}

Acknowledgment is made to Mr Joseph Keane for providing the program to carry out the analysis and to Australian Bureau of Meteorology for providing the daily rainfall data.

\section{REFERENCES}

Coombes, P.J., Kuczera, G. and Kalma, J.D. (2003). Economic water quantity and quality impacts from the use of a rainwater tank in the inner city. Australian Journal of Water Resources, 7(2), 25-36.

Domenech, L. and Sauri, D. (2010). A Comparative appraisal of the use of rainwater harvesting in single and multi-family buildings of the metropolitan area of Barcalona (Spain): social experience, drinking water savings and economic costs. Journal Cleaner Production, 11, 1-11.

Eroksuz, E., and Rahman, A. (2010). Rainwater tanks in multi-unit buildings: A case study for three Australian cities. Resources, Conservation \& Recycling, 54, 1449-1452.

Ghisi, E., Fonseca, D.T., and Rocha V.L. (2009). Rainwater harvesting in petrol stations in Brasilia: Potential for potable water savings and investment feasibility analysis. Resources, Conservation \& Recycling, 54, 79-85.

Imteaz, M.A., Shanableh, A., Rahman, A. and Ahsan, A. (2011a).Optimisation of rainwater tank design from large roofs: a case study in Melbourne, Australia. Resources, Conservation \& Recycling, 55, 1022-29.

Imteaz, M.A., Ahsan, A., Naser, J. and Rahman, A. (2011b). Reliability Analysis of Rainwater Tanks in Melbourne using Daily Water Balance Model. Resources, Conservation \& Recycling, 56, 80-86.

Imteaz, M.A., Rahman, A. and Ahsan, A. (2012). Reliability analysis of rainwater tanks: A comparison between South East and Central Melbourne. Resources, Conservation \& Recycling, 66, 1-7.

Imteaz, M.A., Ahsan, A. and Shanableh, A. (2013). Reliability analysis of rainwater tanks using daily water balance model: variations within a large city. Resources, Conservation \& Recycling, 77, 37-43.

Kus, B., Kandasamy, J., Vigneswaran, S., and Shon, H.K. (2011). Water quality in rainwater tanks in rural and metropolitan areas of New South Wales, Australia. Journal of Water Sustainability, 1(1), 33-43.

Rahman, A., Keane, J. and Imteaz, M.A. (2012). Rainwater Harvesting in Greater Sydney: Water savings, reliability and economic benefits. Resources, Conservation \& Recycling, 61, 16-21.

Su, M., Lin, C., Chang, L., Kang, J. and Lin, M. (2009). A probabilistic approach to rainwater harvesting systems design and evaluation. Resources, Conservation \& Recycling, 53, 393-99.

Van der Sterren, M., Rahman, A. and Dennis, G. (2013). Quality and quantity monitoring of five rainwater tanks in Western Sydney, Australia. Journal of Environmental Engineering, 139, 332-340.

Van der Sterren, M., Rahman, A. and Dennis, G.R. (2012). Implications to stormwater management as a result of lot scale rainwater tank systems: a case study in Western Sydney, Australia, Water Science and Technology, 65, 8, 1475-1482.

Van der Sterren, M., Rahman, A., Shrestha, S., Barker, G. and Ryan, G. (2009). An overview of on-site retention and detention policies for urban stormwater management in the greater Western Sydney region in Australia, Water International, 34: 362-372. 